application forms from Brussels were so badly drawn up that nearly everyone requested further clarification.

The delay is due to confusion over how to incorporate political as well as scientific criteria into its assessment, with priority given to applicants from poorer countries. But EC officials cannot extend the deadline for applications because the ECU109 million available for 1992 will be lost if it is not spent by the end of the year. Late applications will be considered in 1993.

Although these problems provide a disincentive to many scientists, the lure of EC funds is irresistible. Young research fellows are offered salaries at nearly twice the going rate; at ECU45,000, they compare with those paid to department heads. Norman Bowery, professor of pharmacology at the University of London's School of Pharmacy, says that the short deadlines and ambiguous application forms put a lot of pressure on researchers, "but we can't not do it. There is so much money to be had."

In addition, researchers from poorer countries welcome the opportunity to compete for grants from outside their own governments. Rebecca Matsas, senior researcher in neurobiology at the Hellenic Research Institute in Athens, believes that the process is useful even if no grant is made. "It's hectic, but the interactions give you a chance to get to know a lot of people", she says. "It's good for future collaborations."

Alison Abbott

\section{Scientific panel continues work on whaling ban}

London. The moratorium on commercial whaling remains in place following last week's meeting of the International Whaling Commission (IWC) in Glasgow. Although a Revised Management Procedure that the commission's scientific committee had been working on for the past seven years was accepted (see Nature 357, 350; 1992), it must clear other administrative hurdles before it takes effect.

During the next 12 months, the scientific committee must develop minimum data standards, guidelines for conducting surveys and analysing the results and relevant computer programs. All this must be written into language that can withstand legal scrutiny.

Although a French plan to create an Antarctic sanctuary was withdrawn before the meeting opened, the commission decided to review the proposal for its next meeting, a year from now, in Japan. A working group of the scientific committee will hold meetings with such groups as the Commission for the Conservation of Antarctic Marine Living Resources and the Scientific Committee for Antarctic Research.

lan Mundell

\title{
US oceanography lab sinks under weight of politics
}

Even congressional pork can go off. On 30 September, the US Navy will close its Institute for Naval Oceanography (INO) at Bay St Louis, Mississippi, thus dismantling part of the monument to himself that John Stennis built over a 42-year career in the US Senate. The collapse of the laboratory may be a warning that those who rely on powerful congressmen for launching new projects may find themselves stranded once those backers are gone or lose interest.

INO, the youngest of several naval projects at what is known as the Stennis Space Center, results from a deal struck in 1985 between Stennis, then a senior member of the Senate Armed Forces Committee and chairman of the Appropriations Committee, and John Lehman, then Secretary of the Navy. Stennis, angered by Lehman's decision to base in San Francisco a battleship he had coveted for Mississippi, was placated with the INO, planned as a bridge between the Navy and the academic research community. Among other things, INO would have used supercomputers and remote sensing data to forecast oceanographic conditions, much as meteorology has made weather forecasting possible.

Lehman's decision to locate INO in Mississippi contradicted the scientific advice and also the wishes of those nominated to work there, who favoured the Navy's research complex at Monterey, California. But Christopher Mooers, INO's first director, began on an upbeat note, with a staff of 30 and an annual budget of $\$ 4$ million and the ambition to attract others "with a pioneering spirit" (see Nature 324, 6; 1986).

But it has since been downhill all the way. The budget has steadily declined to $\$ 3.2$ million, about two-thirds the value of that in 1986. The Cray Y-MP on which INO had set its heart went to the Oceanographer of the Navy instead (but INO researchers are allowed to use it). Mooers was forced to resign in 1989 after a management dispute, and since then there have been three directors. Mooers says that most of the original staff have left, like many of their successors. "Retention has turned out to be even more difficult than recruitment", he points out.

Where does the blame lie? Most people give Stennis the lion's share, both for snatching INO from its preferred site in California and for his almost total lack of interest afterwards. "It was the barrel without the pork", says Mooers.

INO, created as a civilian centre to encourage cooperation between the Navy and universities, has been managed from the outset by the University Consortium for Atmospheric Research (UCAR), a group of 59 universities with interests in atmospheric research and oceanography. But the pairing proved to be a poor fit. UCAR's only members in southern states are from Florida and Texas. INO also suffered from the successive reorganizations of naval research, which have finally put it under the wing of the Naval Research Laboratory, which has its own university collaborations and has not

Christopher Mooers, former INO director (left); aerial view of institute (below). been looking for UCAR's help.

Wayne Shiver, assistant to UCAR's president, says it has been clear from the start that the Navy would never provide the funds needed to let its newest and weakest research institution attain critical mass. In addition to insufficient funding, INO also suffered from the absence of a meaningful strategic plan and a vision of its place in the Navy's world. UCAR threw in the towel earlier this year, notifying the Navy that it wished to end its responsibility for INO. That was the death knell for the laboratory.

It remains to dismember INO, keeping the pieces worth saving. The ocean modelling programme will probably go to the University of Southern Mississippi and the Experimental Center for Mesoscale Ocean Prediction to Mississippi State University. The Navy will guarantee funds for two years, but then the programmes will have to compete for further grants. Most of the 31 people still at INO, including about 20 scientists, will be kept in one capacity or another. "We're trying to make the best of a bad situation", says Shiver.

Christopher Anderson 